\title{
Gut mucosal and plasma concentrations of glutamine: a comparison between two enriched enteral feeding solutions in critically ill
} patients

\author{
Jean-Charles Preiser ${ }^{1}$, Daliana Peres-Bota ${ }^{2}$, Pierre Eisendrath ${ }^{3}$, Jean- \\ Louis Vincent*2 and André Van Gossum ${ }^{3}$
}

\begin{abstract}
Address: ${ }^{1}$ Department of Intensive Care, Centre Hospitalier Universitaire de Liège, Belgium, ${ }^{2}$ Department of Intensive Care, Erasme University Hospital, Brussels, Belgium and ${ }^{3}$ Department of Gastroenterology, Erasme University Hospital, Brussels, Belgium

Email: Jean-Charles Preiser - jean-charles.preiser@chu.ulg.ac.be; Daliana Peres-Bota - peresdaliana@yahoo.fr;

Pierre Eisendrath - andre.van.gossum@ulb.ac.be; Jean-Louis Vincent* - jlvincen@ulb.ac.be; André Van Gossum - andre.van.gossum@ulb.ac.be

* Corresponding author
\end{abstract}

Published: 13 October 2003

Nutrition Journal 2003, 2:13

This article is available from: http://www.nutritionj.com/content/2/I/13

(c) 2003 Preiser et al; licensee BioMed Central Ltd. This is an Open Access article: verbatim copying and redistribution of this article are permitted in all media for any purpose, provided this notice is preserved along with the article's original URL.

\begin{abstract}
Background: Addition of glutamine to enteral nutrition formulas is consistently associated with a significant decrease in septic morbidity in critically ill patients, possibly related to the attenuation of gut dysfunction. This pilot study was undertaken to compare the effects of enteral administration of two glutamine-enriched formulas containing either additional free glutamine or glutamine-rich proteins, with a standard solution on plasma and mucosal concentrations of glutamine in patients admitted in the Department of Intensive Care.

Methods: Following randomization, glutamine concentration was determined in endoscopically sampled duodenal biopsies and plasma, before and after a 7-day period of continuous administration of the designated solution.

Results: The mucosal concentration of glutamine increased in the duodenal biopsies sampled from patients randomized to the solution containing the glutamine-rich proteins (from $3.6 \pm 2.2$ to 6.7 $\pm 5.2 \mathrm{micro}-\mathrm{mol} / \mathrm{g}$ protein), but not from the others. There were no differences between the 3 groups in the plasma concentrations of glutamine, which remained stable over time.
\end{abstract}

Conclusion: The source of supplemental glutamine can influence gut mucosal glutamine concentrations, suggesting differences in its availability or utilization.

\section{Background}

Addition of glutamine to the nutritional support provided to critically ill patients has been suggested, namely to prevent gut dysfunction and subsequent multiple organ failure. The beneficial effects of glutamine supplementation to critically ill patients have been shown in at least two controlled studies $[1,2]$, where patients randomized to a glutamine-enriched regimen had improved long-term sur- vival [1] and reduced septic morbidity [2]. Although incompletely elucidated, the beneficial effects of these enriched solutions may have been related to the intestinal effects of glutamine. Reported intestinal effects of glutamine include the maintenance of gut barrier function, intestinal cell proliferation and differentiation, increased DNA and protein content and synthesis, and decreased production of pro-inflammatory cytokines [3- 
9]. The intestinal extraction rate of glutamine is higher than other amino acids [10,11].

The enteral route is preferred for nutritional support in critically ill patients [12]. In addition, the gut barrier function is better preserved when glutamine is supplied on the apical rather than the basolateral side of the enterocyte [13]. Therefore, the enrichment of the glutamine content of enteral feeding solutions is a logical and attractive therapeutic approach. New feeding formulas including supplemental glutamine (13-15 g/L) have been marketed recently. Glutamine is added in its free (unbound) form immediately before use of the solution, or is already present in the vegetal proteins incorporated in the solution.

This pilot study compared the effects of these solutions on the gut and plasma concentrations of glutamine, in order to select one for future studies on gut functional parameters.

\section{Methods}

This prospective, randomized, single-blind, placebo-controlled, pilot study enrolled adult patients referred to the Department of Intensive Care of the Erasme University Hospital. The hospital ethic's committee approved the study and signed consent was obtained from the patients' next-of-kin. The inclusion criteria consisted of a loss of consciousness and a reasonable expectation of at least 7 days' requirement for nutritional support and survival. Exclusion criteria consisted of any contra-indication to naso-gastric tubing, eso-gastro-duodenal endoscopy, duodenal biopsy (prothrombin time $<60 \%$ and/or platelet count $<100,000 / \mathrm{mm}^{3}$ ) or the absence of signed informed consent.

At the time of inclusion, primary diagnosis and usual demographic parameters were recorded. Arterial blood samples were drawn at inclusion, centrifuged (3000 rpm for $10 \mathrm{~min})$ and stored $\left(-80^{\circ} \mathrm{C}\right)$ for the determination of plasma glutamine concentration. After intravenous infusion of butylscopolamine ( $40 \mathrm{mg}$ ), an oeso-gastro-duodenal endoscopy was performed (Olympus, PCF10, Tokyo, Japan), and 8 duodenal biopsies were sampled. The samples were kept in dry tubes at $-80^{\circ} \mathrm{C}$.

Patients were then randomized using a computerized random number table and sealed envelopes to receive the control solution (Nutrison Standard ${ }^{\circledR}$, Nutricia, Bornem, Belgium), the free glutamine-enriched solution (Alitraq ${ }^{\circledR}$, Ross-Abbott, Columbus, $\mathrm{OH}$ ), or the solution containing glutamine from wheat-derived proteins (Stresson ${ }^{\circledR}$, Nutricia, Bornem, Belgium). The solutions were kindly provided by their respective manufacturers. The composition of the solutions is detailed in the table 1.
Table I: Composition of the formulas

\begin{tabular}{lccc}
\hline Per $\mathbf{1 0 0 ~} \mathbf{~ m L}$ & $\begin{array}{c}\text { Nutrison } \\
\text { Standard }\end{array}$ & AlitraQ & Stresson \\
\hline Caloric density (kcal) & 100 & 100 & 125 \\
Proteins $(\mathrm{g})$ & 4 & 5.25 & 7.5 \\
Fat $(\mathrm{g})$ & 3.90 & 1.55 & 4.17 \\
Carbohydrates $(\mathrm{g})$ & 12.3 & 16.5 & 14.5 \\
Protein-bound glutamine $(\mathrm{g})$ & 0.40 & 0 & 1.30 \\
Total glutamine content $(\mathrm{g})$ & 0.40 & 1.54 & 1.30 \\
\hline
\end{tabular}

The solutions were continuously administered at a rate of $30 \mathrm{~mL} / \mathrm{h}(720 \mathrm{~mL} /$ day $)$ from day 0 to day 1 , and at a rate of $60 \mathrm{~mL} / \mathrm{h}(1440 \mathrm{~mL} /$ day) from day 1 to day 7 , using a peristaltic pump. Gastric residues were checked once daily and the administration was interrupted for 4 hours if it was higher than $300 \mathrm{~mL}$, and a pro-kinetic agent (Cisapride, Prepulsid ${ }^{\oplus}$, Janssen, Beerse, Belgium) was then prescribed. In the case of diarrhea, the administration rate was slowed by half and an anti-diarrheal medication (Loperamide, Imodium ${ }^{\circledast}$, Janssen) was administered. The patients were dropped from the study if they recovered the ability to eat before the end of the 7-day period. Plasma and duodenal samples were taken on day 7 , four hours after administration of the feeding solution was stopped. Patient outcome was followed until ICU discharge.

For determination of plasma glutamine, blood was centrifuged (3000 rpm for 10 minutes) and the plasma was stored at $-70^{\circ} \mathrm{C}$. The duodenal biopsies were immediately frozen at $-70^{\circ} \mathrm{C}$. Once defrosted, the duodenal tissue was homogenized. Determination of glutamine concentration by selected ion monitoring quantification by gas chromatography/mass spectrometry (GCMS), using HFBAglutamine [14].

Statistical analysis included an analysis of variance for repeated measures and a Student's $t$-test for comparison of the biochemical parameters between day 7 and baseline. A p value $<0.05$ was considered as significant. Results are expressed as mean \pm standard deviation (SD).

\section{Results}

This study was performed over an 8-month period. A total of 12 patients were eligible, of whom two died and one recovered the ability to eat during the study period. The characteristics of the 9 remaining patients are shown in Table 2. Mean age was $57 \pm 11$ years.

Over the 7-day study period, the patients actually received $80-90 \%$ of the prescribed amount of their designated solution, i.e., Nutrison Standard $(7600 \pm 2447 \mathrm{~mL})$, Ali- 
Table 2: Characteristics of the patients

\begin{tabular}{llllll}
\hline & Age & Formula & Gender & Diagnosis at the time of admission & ICU Outcome \\
\hline $\mathbf{I}$ & 52 & NTS & F & Meningo-encephalitis - Cerebral aneurysm & Deceased \\
$\mathbf{2}$ & 75 & NTS & M & Spontaneous intracerebral hemorrhage & Survived \\
$\mathbf{3}$ & 49 & NTS & M & Post-anoxic encephalopathy & Survived \\
$\mathbf{4}$ & 62 & ALI & F & Subarachnoid hemorrhage & Survived \\
$\mathbf{5}$ & 49 & ALI & F & Subarachnoid hemorrhage & Survived \\
$\mathbf{6}$ & 37 & ALI & F & Spontaneous intracerebral hemorrhage & Survived \\
$\mathbf{7}$ & 55 & STR & F & Cerebral trauma & Survived \\
$\mathbf{8}$ & 64 & STR & F & Post-surgical cerebral hemorrhage & Survived \\
$\mathbf{9}$ & 67 & STR & F & Subarachnoid hemorrhage & Survived \\
\hline
\end{tabular}

$\operatorname{traQ}(8430 \pm 217 \mathrm{~mL})$, or Stresson $(8433 \pm 1100 \mathrm{~mL})$. The total amounts of glutamine received were $30.4 \pm 9.8 \mathrm{~g}$, $129.8 \pm 3.3 \mathrm{~g}$ and $109.6 \pm 15.4 \mathrm{~g}$ for Nutrison Standard, AlitraQ and Stresson, respectively.

Plasma glutamine concentrations (Fig 1, upper panel) increased slightly from $322 \pm 84 \mu \mathrm{mol} / \mathrm{L}$ at baseline to 389 $\pm 134 \mu \mathrm{mol} / \mathrm{L}$ (NS). There was no significant difference in the time course of the plasma glutamine concentration between the groups.

In each patient randomized to "Stresson", mucosal glutamine concentrations increased to reach 1.3-2.0 times the baseline value at the end of the 7-day period. Hence, the values of mucosal concentrations of glutamine increased from $3.86 \pm 1.37$ to $4.71 \pm 3.25 \mu \mathrm{mol} / \mathrm{g}$ protein in the "Stresson" group. There was no change in the other groups (Fig 1, lower panel).

\section{Discussion}

This pilot study suggests that the mucosal glutamine concentration was increased after administration of an enteral feeding solution containing glutamine-rich proteins but not additional free glutamine.

The duodenal samples were taken approximately 20-30 $\mathrm{cm}$ distally to the tip of the naso-gastric catheter, as in a previous study of enteral glutamine absorption in volunteers [15]. The discontinuation of the administration of the enteral solution four hours before the second duodenal sampling may represent a limitation to the interpretation of the results. However, this delay was the shortest possible to allow appropriate viewing and sampling of a duodenal biopsy, especially in this patient population in whom gastric emptying is often delayed.

Three studies have investigated the effects of glutamineenriched enteral solutions in critically ill patients $[2,16,17]$. The solutions used in these studies were enriched with free glutamine. In the two studies using Ali-
traQ $[2,16]$, as in the present one, the plasma concentrations of glutamine in the samples drawn were not increased after 7 days, probably because glutamine is rapidly metabolized. The baseline glutamine concentrations measured in the present study were in the same range as previously reported in critically ill patients $[2,16,18]$. In volunteers, the peak post-absorptive plasma glutamine concentration was higher after ingestion of glutamine in its free form than protein-bound [19], while the splanchnic extraction was similar [10]. In contrast, our data indicate that the mucosal concentration of glutamine can be influenced by the source of glutamine. However, an increase in the mucosal concentration may indicate an enhanced availability or a reduced utilization of glutamine, but provides no information about the concentration of glutamine in different cell types. Importantly, the absorption of peptides can be better than that of free amino-acids [20].

A limitation of this pilot study lies on the small size of the study population, which does not allow statistical analysis. However, these data could be of interest for the selection of an enteral formula for future studies on the effects of glutamine on gut physiology.

In conclusion, the data presented here suggest that the source of glutamine in enteral formulas can influence its metabolism. Further studies are required to assess whether this can translate into an improvement in intestinal function and a clinical benefit.

\section{Competing interests}

None declared

\section{Authors' contributions}

JCP, DBP and JLV collected and analysed the data. PE and AVG performed the endoscopies and biopsies. 


\section{Plasma GLN concentration ( $\mu \mathrm{mol} / \mathrm{L})$}

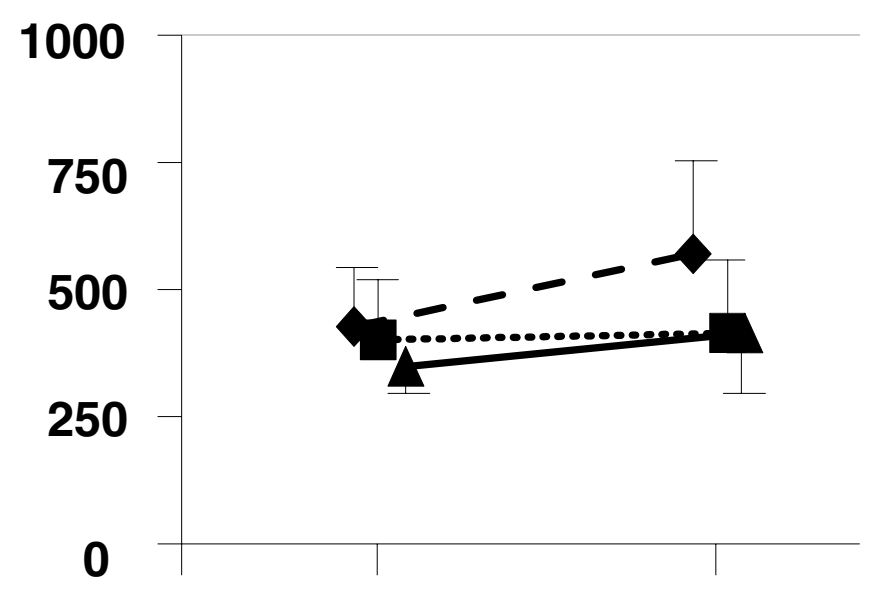

\section{Mucosal GLN concentration ( $\mu \mathrm{mol} / \mathrm{g}$ protein)}

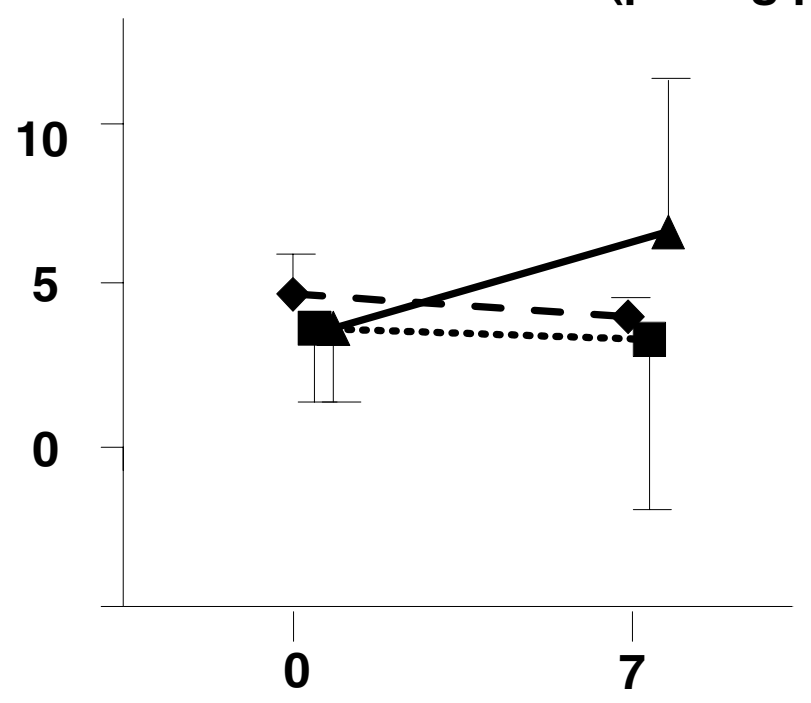

Time

(days)

\section{Figure I}

Concentrations of glutamine (mean $\pm S D$ ) in samples drawn from patients randomized to Nutrison Standard (broken line, diamonds), Alitraq (dotted line, squares) or Stresson (continuous line, triangles). The samples were taken before (day 0 ) and after (day 7) administration of the designated formula. 


\section{Acknowledgements}

The authors acknowledge the excellent technical assistance of Michèle Schroeder and the assistance of Dominique Darmaun and Bernard Humbert (INSERM Nantes, France) in the determination of glutamine concentrations.

\section{References}

I. Griffiths RD, Jones C and Palmer TE: Six-month outcome of critically ill patients given glutamine- supplemented parenteral nutrition. Nutrition I 997, I 3:295-302.

2. Houdijk AP, Rijnsburger ER, Jansen J, Wesdorp RI, Weiss JK, McCamish MA, Teerlink T, Meuwissen SG, Haarman HJ, Thijs LG and van Leeuwen PA: Randomised trial of glutamine-enriched enteral nutrition on infectious morbidity in patients with multiple trauma. Lancet 1998, 352:772-776.

3. Bouteloup-Demange C, Claeyssens S, Maillot C, Lavoinne A, Lerebours $E$ and Dechelotte $P$ : Effects of enteral glutamine on gut mucosal protein synthesis in healthy humans receiving glucocorticoids. Am J Physiol Gastrointest Liver Physiol 2000, 278:G677-G68I.

4. Coeffier M, Miralles-Barrachina O, Le Pessot F, Lalaude O, Daveau M, Lavoinne A, Lerebours $E$ and Dechelotte $P$ : Influence of glutamine on cytokine production by human gut in vitro. Cytokine $200 \mathrm{I}$, I 3: |48-I54.

5. Daniele B, Perrone F, Gallo C, Pignata S, De Martino S, De Vivo R, Barletta E, Tambaro R, Abbiati R and D'Agostino L: Oral glutamine in the prevention of fluorouracil induced intestinal toxicity: a double blind, placebo controlled, randomised trial. Gut 2001, 48:28-33.

6. Murnin M, Kumar A, Li GD, Brown M, Sumpio BE and Basson MD: Effects of glutamine isomers on human (Caco-2) intestinal epithelial proliferation, strain-responsiveness, and differentiation. J Gastrointest Surg 2000, 4:435-442.

7. Souba WW, Klimberg VS, Hautamaki RD, Mendenhall WH, Bova FC, Howard RJ, Bland $\mathrm{KI}$ and Copeland EM: Oral glutamine reduces bacterial translocation following abdominal radiation. J Surg Res 1990, 48: I-5.

8. van der Hulst RR, van Kreel BK, von Meyenfeldt MF, Brummer RJ, Arends JW, Deutz NE and Soeters PB: Glutamine and the preservation of gut integrity. Lancet 1993, 34 I: I363-1365.

9. Ziegler TR, Young LS, Benfell K, Scheltinga M, Hortos K, Bye R, Morrow FD, Jacobs DO, Smith RJ, Antin JH and .: Clinical and metabolic efficacy of glutamine-supplemented parenteral nutrition after bone marrow transplantation. A randomized, double- blind, controlled study. Ann Intern Med 1992, I | 6:821-828.

10. Boza JJ, Dangin M, Moennoz D, Montigon F, Vuichoud J, Jarret A, Pouteau E, Gremaud G, Oguey-Araymon S, Courtois D, Woupeyi A, Finot PA and Ballevre $O$ : Free and protein-bound glutamine have identical splanchnic extraction in healthy human volunteers. Am J Physiol Gastrointest Liver Physiol 2001, 28I:G267-G274.

II. McAnena OJ, Moore FA, Moore EE, Jones TN and Parsons P: Selective uptake of glutamine in the gastrointestinal tract: confirmation in a human study. Br J Surg 1991, 78:480-482.

12. Preiser JC, Berre J, Carpentier Y, Jolliet P, Pichard C, Van Gossum A and Vincent JL: Management of nutrition in European intensive care units: results of a questionnaire. Working Group on Metabolism and Nutrition of the European Society of Intensive Care Medicine. Intensive Care Med I999, 25:95-I0I.

13. Panigrahi P, Gewolb IH, Bamford $P$ and Horvath K: Role of glutamine in bacterial transcytosis and epithelial cell injury. JPEN J Parenter Enteral Nutr 1997, 2 I:75-80.

14. Darmaun D, Manary MJ and Matthews DE: A method for measuring both glutamine and glutamate levels and stable isotopic enrichments. Anal Biochem 1985, 147:92-102.

15. Dechelotte P, Darmaun D, Rongier M, Hecketsweiler B, Rigal $O$ and Desjeux JF: Absorption and metabolic effects of enterally administered glutamine in humans. Am J Physiol 1991, 260:G677-G682.

16. Jensen GL, Miller RH, Talabiska DG, Fish J and Gianferante L: A double-blind, prospective, randomized study of glutamineenriched compared with standard peptide-based feeding in critically ill patients. Am J Clin Nutr 1996, 64:6I5-62I.
17. Jones C, Palmer TE and Griffiths RD: Randomized clinical outcome study of critically ill patients given glutamine-supplemented enteral nutrition. Nutrition 1999, I 5: 108-I I5.

18. Ahlman B, Ljungqvist $O$, Persson B, Bindslev $L$ and Wernerman J: Intestinal amino acid content in critically ill patients. JPEN J Parenter Enteral Nutr 1995, 19:272-278.

19. Boza JJ, Maire J, Bovetto L and Ballevre O: Plasma glutamine response to enteral administration of glutamine in human volunteers (free glutamine versus protein-bound glutamine). Nutrition 2000, I 6: 1037-1042.

20. Silk DB: Progress report. Peptide absorption in man. Gut I974, I 5:494-50|.
Publish with Bio Med Central and every scientist can read your work free of charge

"BioMed Central will be the most significant development for disseminating the results of biomedical research in our lifetime. "

Sir Paul Nurse, Cancer Research UK

Your research papers will be:

- available free of charge to the entire biomedical community

- peer reviewed and published immediately upon acceptance

- cited in PubMed and archived on PubMed Central

- yours - you keep the copyright

Submit your manuscript here:

http://www.biomedcentral.com/info/publishing_adv.asp 